\title{
Major influence of CD4 count at the initiation of CART on viral and immunological reservoir constitution in HIV-1 infected patients
}

\author{
Anne-Emmanuelle Depincé-Berger ${ }^{1,2 \dagger}{ }^{\dagger}$, Delphine Vergnon-Miszczychaa ${ }^{1,3 \dagger}$, Alexandre Girard ${ }^{1}$, Anne Frésard ${ }^{3}$, \\ Elisabeth Botelho-Nevers ${ }^{1,3}$, Claude Lambert ${ }^{1,2}$, Emilie Del Tedesco ${ }^{4}$, Christian Genin ${ }^{1,2}$, Bruno Pozzetto 1,5, \\ Frédéric Lucht ${ }^{1,3}$, Xavier Roblin ${ }^{1,4}$, Thomas Bourlet ${ }^{1,5^{*}+}$ and Stéphane Paul $1^{1,2+}$
}

\begin{abstract}
Background: A persistent immune activation is observed in gut during HIV-1 infection, which is not completely reversed by a combined antiretroviral therapy (CART). The impact of the time of CART initiation may highly influence the size of the viral reservoir and the ratio of $\mathrm{CD}^{+} / \mathrm{CD}^{+} \mathrm{T}$ cells in the gut. In this study, we analyzed the characteristics of HIV rectal reservoir of long-term treated patients, regarding their blood $C D 4^{+} T$ cells count at the time of cART initiation.

Results: Twenty-four consenting men were enrolled: 9 exhibiting a CD4 ${ }^{+} \mathrm{T}$ cells count $>350 / \mathrm{mm}^{3}$ ("high-level CD4 group") and $15<350 / \mathrm{mm}^{3}$ ("low-level CD4 group") in blood, at the start of CART. An immunophenotypical analysis of T and B cells subpopulations was performed in blood and rectal biopsies. HIV cell-associated DNA loads and qualitative intra-cellular RNA were determined in both compartments. The ratio of $\mathrm{CD} 4^{+} / \mathrm{CD} 8^{+} \mathrm{T}$ cells was significantly decreased in the blood but not in the rectum of the "low-level CD4 group" of patients. The alteration in $\beta 7^{+} \mathrm{CD} 4^{+} \mathrm{T}$ cells homing was higher in this group and was correlated to a low ratio of $\mathrm{CD} 4^{+} / \mathrm{CD} 8^{+} T$ cells in blood. An initiation of CART in men exhibiting a low-level CD4 count was also associated with an alteration of B cells maturation. HIV blood and gut DNA reservoirs were significantly lower in the "high-level CD4 group" of men. A high HIV DNA level was associated to a detectable intracellular HIV RNA in rectum.
\end{abstract}

Conclusions: An early initiation of CART could significantly preserve gut immunity and limit the viral reservoir constitution.

Keywords: HIV, CART, GALT, Homing, Reservoir

\section{Background}

Although combined antiretroviral therapy (cART) has dramatically improved the quality of life and lifespan of HIV infected individuals, it still fails to eliminate viral reservoirs. The Gut Associated Lymphoid Tissue (GALT) is the largest reservoir of HIV-1, as it harbors most of

\footnotetext{
*Correspondence: thomas.bourlet@chu-st-etienne.fr

${ }^{\dagger}$ Anne-Emmanuelle Depincé-Berger, Delphine Vergnon-Miszczycha,

Thomas Bourlet and Stéphane Paul contributed equally to this work

${ }^{1}$ Groupe Immunité des Muqueuses et Agents Pathogènes - GIMAP

EA 3064, CIC 1408, Faculté de Médecine J. Lisfranc, Université de

Saint-Etienne, Université de Lyon, 42023 Saint-Étienne Cedex 02, France

Full list of author information is available at the end of the article
}

HIV target cells as activated memory $\mathrm{CD} 4^{+} / \mathrm{CCR} 5^{+} \mathrm{T}$ cells $[1,2]$. Intestinal $T$ and $B$ cells express $\alpha 4 \beta 7$ integrin, a gut mucosal homing receptor which binds to gp120 HIV-1 envelope, facilitating the infection of intestinal T cells and the early establishment of the gut HIV reservoir [3]. Intensive viral replication in the GALT leads to an early impairment of mucosal immunity, due to the severe $\mathrm{CD} 4^{+} \mathrm{T}$ cells depletion, that could also be explained by a lack of recruitment in the gut $[4,5]$. Among T cells, IL-17 secreting $\mathrm{CD}_{4}^{+} \mathrm{T}$ cells (Th17) are particularly depleted during HIV infection [6]. This depletion could be associated with HIV progression since these cells play a crucial role in the maintenance of mucosal immunity [6]. This 
proinflammatory activity is balanced by regulatory $\mathrm{T}$ cells (Treg) and a dysbalance of the Th17/Treg ratio may reflect the loss of the intestinal epithelial barrier integrity $[7,8]$. During HIV infection, Treg cells are highly recruited into the GALT, which increase the imbalance with Th17 cells [9]. These damages are responsible for an increase in microbial translocation, which is associated with immune activation and progression to AIDS [1014]. B cells compartment has been poorly studied but it seems to be affected very early during HIV infection, with a global hyperactivity, partially reversed by cART $[15,16]$. However, the influence of cART on B cells rescue remains unknown [15].

Several recent studies have shown that cART initiation during acute or early HIV-1 infection reduces HIV DNA reservoir size and improves the ratio of $\mathrm{CD}^{+} /$ $\mathrm{CD}^{+} \mathrm{T}$ cells in blood [17-20]. Post-treatment controllers (PTc), who started long-term cART early after HIV infection, have very low levels of HIV DNA in peripheral blood mononuclear cells (PBMC), similarly to elite controllers [21]. Unlike most HIV-infected individuals, they maintain an undetectable plasmatic viral load after several years of cART interruption, suggesting that a weak reservoir is a prerequisite to achieve a functional cure [21]. By extrapolation, it could be hypothesized that the gut viral reservoir is also decreased and that mucosal immunity is restored when cART is initiated during the primary phase of infection. In a monkey lab model, the initiation of suppressive cART 3 days after the infection blocked the emergence of viral RNA and proviral DNA in blood and reduced the size of viral reservoir in lymph nodes and GALT [22].

The gut viral reservoir begins to form within the first days after HIV exposure, and grows during acute HIV infection [23]. Similarly, intestinal T cells are depleted directly after infection [5], due to high viral replication, host immune response and bystander effects [24]. Most studies also concluded that long-term and optimal treatment can't fully restore mucosal immunity [25]. These observations led us to study the impact of time of cART start on the size of viral reservoir and on the ratio of $\mathrm{CD}^{+} / \mathrm{CD}^{+} \mathrm{T}$ cells in the gut. For this, we analyzed the virological and immunological characteristics of the rectal HIV reservoir of long-term treated patients, regarding their blood $\mathrm{CD} 4^{+} \mathrm{T}$ cells count at the time of cART initiation.

\section{Results}

Twenty-four men were enrolled between May 2013 and March 2015. For 9 patients ("high-level CD4 group"), cART was initiated when the number of $\mathrm{CD}^{+} \mathrm{T}$ cells was over $350 \mathrm{CD}^{+} \mathrm{T}$ cells $/ \mathrm{mm}^{3}\left[398-1025 / \mathrm{mm}^{3}\right]$. For 15 ("low-level CD4 group"), cART was initiated when the number of $\mathrm{CD}^{+} \mathrm{T}$ cells was below $350 \mathrm{CD}^{+} \mathrm{T}$ cells/ $\mathrm{mm}^{3}\left[14-347 / \mathrm{mm}^{3}\right]$. The number of $350 \mathrm{CD}^{+} \mathrm{T}$ cells/ $\mathrm{mm}^{3}$ was considered, since it has been suggested that mortality and disease progression is reduced if cART is started in patients exhibiting blood $\mathrm{CD} 4^{+} \mathrm{T}$ cells load above this threshold [26]. The cART was initiated during primary HIV infection (PHI, Fiebig III score [27]) in four patients, three belonging to "high-level CD4 group", and one to "low-level CD4 group". Detailed results of their immunophenotypical and virological markers are shown in Table 1.

\section{Initiation of CART with high level of CD4 is associated with an elevation of the ratio $\mathrm{CD} 4^{+} / \mathrm{CD}^{+} \mathrm{T}$ cells in blood but not in GALT (Fig. 1 and Additional file 1: Figure S1 and Additional file 2: Fig. S2)}

Overall, the ratio $\mathrm{CD} 4^{+} / \mathrm{CD} 8^{+} \mathrm{T}$ cells was significantly higher in blood than in rectum $(0.8[0.5-1.1]$ vs 0.4 $[0.2-0.6], p=0.0023)$. In blood, it was significantly correlated to the $\mathrm{CD}_{4}^{+} \mathrm{T}$ cells count at the initiation of cART $(\mathrm{r}=0.48, \mathrm{p}=0.02)\left(\right.$ Fig. $\left.1 \mathrm{a}_{1}\right)$, but not in rectum $(\mathrm{r}=0.28$, $\mathrm{p}=0.21)$. The exhausted/hyperactivated phenotype of $\mathrm{T}$ cells $\left(\mathrm{PD} 1^{+}\right)$was higher in the rectum than in the blood (MFI of the gated $\mathrm{CD} 4^{+} / \mathrm{PD} 1^{+}$population 35.9 [23.151.4] vs 16.9 [16.2-17.8], $\mathrm{p}<0.0001$ and MFI of the gated $\mathrm{CD}^{+} / \mathrm{PD} 1^{+}$population 29.4 [25.9-41.6] vs 17.7 [17.127.9], $\mathrm{p}=0.002$; Fig. $1 \mathrm{c}-\mathrm{e}$ ) and was not significantly different between the two groups (MFI of $\mathrm{CD}^{+} / \mathrm{PD}^{+} \mathrm{T}$ cells 17.8 [16.9-28] vs 17.7 [16.5-22], $\mathrm{p}=0.79$ in blood and MFI 30.9 [23.9-52.2] vs 38.8 [27.5-44.6], $\mathrm{p}=0.88$ in rectum). The proportion of $\mathrm{p} 24^{+} \mathrm{CD} 4^{+} \mathrm{T}$ cells (among $\mathrm{CD}^{+} \mathrm{T}$ cells) was not significantly different between the 2 groups, in both compartments $(0.71 \%$ [0.26-1.45] in "high-level CD4 group" vs $0.92 \%$ [0.39-1.59] in "lowlevel CD4 group", $\mathrm{p}=0.55$, in blood and $8.62 \%$ [2.97$16.72]$ in "high-level CD4 group" vs $7.23 \%$ [2.42-27.46] in "low-level CD4 group", $\mathrm{p}=0.96$, in rectum). The same findings were observed for the expression of CXCR4 coreceptor (MFI CXCR4 17.78 [15.03-24] in "high-level CD4 group" vs 17.33 [16.69-21.74] in "low-level CD4 group", $\mathrm{p}=0.72$, in blood and MFI CXCR4 17.44 [15.4219.13] in "high-level CD4 group" vs 16.15 [16.02-18.61] in "low-level CD4 group", $\mathrm{p}=0.46$, in rectum) and for the expression of CCR5 co-receptor (MFI CCR5 42.03 [37.82-46.63] in "high-level CD4 group" vs 40.75 [38.4746.23] in "low-level CD4 group", $\mathrm{p}=0.97$, in blood and MFI CCR5 51.01 [43.41-65.4] in "high-level CD4 group" vs 52.64 [45.02-74.96] in "low-level CD4 group", $\mathrm{p}=1$, in rectum). There was no difference of CXCR4 expression in $\mathrm{CD}_{4}{ }^{+} \mathrm{T}$ cells between the two compartments (MFI CXCR4 17.39 [16.43-20.92] in blood vs 16.44 [16.0218.99] in rectum, $\mathrm{p}=0.27$ ), whereas the expression of CCR5 co-receptor in $\mathrm{CD}^{+} \mathrm{T}$ cells was significantly 
Table 1 Main results of immunophenotypical and virological reservoir analysis of patients enrolled in the study according to their $\mathrm{CD}^{+}$cells count at the time of CART initiation

Blood CD4 ${ }^{+} \mathrm{T}$ count at the time of diagnosis $\left(\right.$ cells $\left./ \mathrm{mm}^{3}\right)$

p value

$>350$ "high-level CD4 group" $(n=9) \quad<350$ “low-level CD4 group" $(n=15)$

\begin{tabular}{|c|c|c|c|}
\hline \multicolumn{4}{|l|}{$\mathrm{MFI} \mathrm{CD} 3^{+} / \mathrm{PD} 1^{+} \mathrm{T}$ cells } \\
\hline Blood & $17.8[16.9-28]$ & $17.7[16.5-22]$ & 0.79 \\
\hline Rectum & $30.9[23.9-52.2]$ & $38.8[27.5-44.6]$ & 0.88 \\
\hline \multicolumn{4}{|l|}{ 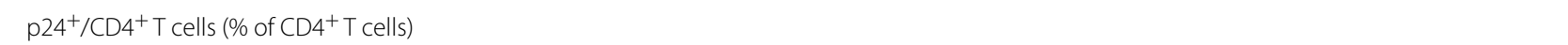 } \\
\hline Blood & $0.71[0.26-1.45]$ & $0.92[0.39-1.59]$ & 0.55 \\
\hline Rectum & $8.62[2.97-16.72]$ & $7.23[2.42-27.46]$ & 0.96 \\
\hline \multicolumn{4}{|l|}{ MFI CXCR4 in CD4 ${ }^{+} \mathrm{T}$ cells } \\
\hline Blood & $17.78[15.03-24]$ & $17.33[16.69-21.74]$ & 0.72 \\
\hline Rectum & 17.44 [15.42-19.13] & $16.15[16.02-18.61]$ & 0.46 \\
\hline \multicolumn{4}{|l|}{ MFI CCR5 in CD4 ${ }^{+} \mathrm{T}$ cells } \\
\hline Blood & $42.03[37.82-46.63]$ & $40.75[38.47-46.23]$ & 0.97 \\
\hline Rectum & $51.01[43.41-65.4]$ & $52.64[45.02-74.96]$ & 1 \\
\hline \multicolumn{4}{|l|}{ Th17 cells/Treg ratio } \\
\hline Blood & $2.9[1.4-4.3]$ & $2.2[1.5-3]$ & 0.64 \\
\hline Rectum & $1.4[1.1-2.8]$ & $1.3[1.1-2.5]$ & 0.96 \\
\hline Blood/rectum ratio of $\beta 7^{+}$expression in $C D 4^{+} T$ cells & $0.9[0.8-1.2]$ & $1.6[1.3-1.8]$ & 0.0006 \\
\hline Blood/rectum ratio of $\beta 7^{+}$expression in $C D 8^{+} T$ cells & $0.7[0.5-1.2]$ & $0.8[0.7-1]$ & 0.54 \\
\hline \multicolumn{4}{|l|}{ MFI CCR9 in CD4 ${ }^{+} \mathrm{T}$ cells } \\
\hline Blood & $9.67[9.29-10.65]$ & $10.13[9.27-11.25]$ & 0.6 \\
\hline Rectum & $18.19[13.93-23.51]$ & $20.02[16.05-25.23]$ & 0.6 \\
\hline \multicolumn{4}{|l|}{ MFI CCR9 in CD8 ${ }^{+} \mathrm{T}$ cells } \\
\hline Blood & $14.03[13.01-20.02]$ & 13.73 [13.19-17.29] & 0.82 \\
\hline Rectum & $19.11[16.41-24.14]$ & $16.36[14.78-18.78]$ & 0.12 \\
\hline \multicolumn{4}{|l|}{ Naive $\mathrm{CD}^{+}{ }^{+} \mathrm{T}$ cells ( $\%$ of $\mathrm{CD} 4^{+} \mathrm{T}$ cells) } \\
\hline Blood & $33.48[27.55-46]$ & $28.63[17.03-42.8]$ & 0.36 \\
\hline Rectum & $5.07[1.96-10.35]$ & $4.99[3.54-7.12]$ & 0.73 \\
\hline \multicolumn{4}{|l|}{$\mathrm{CM} \mathrm{CD} 4^{+} \mathrm{T}$ cells ( $\%$ of $\mathrm{CD} 4^{+} \mathrm{T}$ cells) } \\
\hline Blood & $38.29[31.37-44.25]$ & $37.06[26.74-48.41]$ & 0.97 \\
\hline Rectum & 24.38 [21.39-41.73] & $15.42[12.75-41.48]$ & 0.39 \\
\hline \multicolumn{4}{|l|}{ EM CD4 ${ }^{+} \mathrm{T}$ cells ( $\%$ of $\mathrm{CD} 4^{+} \mathrm{T}$ cells) } \\
\hline Blood & $23.83[11.89-27.31]$ & $22.59[12.78-33.74]$ & 0.55 \\
\hline Rectum & $66.27[53.45-71.44]$ & $67.99[50.44-82.32]$ & 0.49 \\
\hline \multicolumn{4}{|l|}{ EMRA CD4 ${ }^{+} \mathrm{T}$ cells ( $\%$ of $\mathrm{CD} 4^{+} \mathrm{T}$ cells) } \\
\hline Blood & $4.83[1.73-8.08]$ & $2.23[0.55-4.53]$ & 0.22 \\
\hline Rectum & $0.61[0.45-1.77]$ & $0.39[0.12-5.2]$ & 0.66 \\
\hline \multicolumn{4}{|l|}{ Immunophenotypical analysis of B cells } \\
\hline Blood naive lgD ${ }^{+}$B cells (\% of conventional B cells) & $76.6[60.6-79.1]$ & $82.2[77.3-87.6]$ & 0.05 \\
\hline Blood activated lgD- B cells (\% of conventional B cells) & $23.1[20.8-38.8]$ & $17.6[12.4-22.4]$ & 0.05 \\
\hline Memory B cells (\% of conventional B cells) & $5.94[1.68-18.05]$ & $4.05[2.07-5.66]$ & 0.34 \\
\hline \multicolumn{4}{|l|}{ Virological reservoir analysis } \\
\hline \multicolumn{4}{|l|}{ HIV DNA load ( $\log _{10}$ copies/millions of cells) } \\
\hline Blood & $2.41[2.03-2.93]$ & $3.48[3.17-3.7]$ & 0.01 \\
\hline Rectum & $3.06[1.93-3.63]$ & $3.6[3.4-4.08]$ & 0.04 \\
\hline
\end{tabular}

Medians of MFI or percentages [range]

$C M$ central memory, EM effector memory, EMRA effector memory T cells expressing RA 

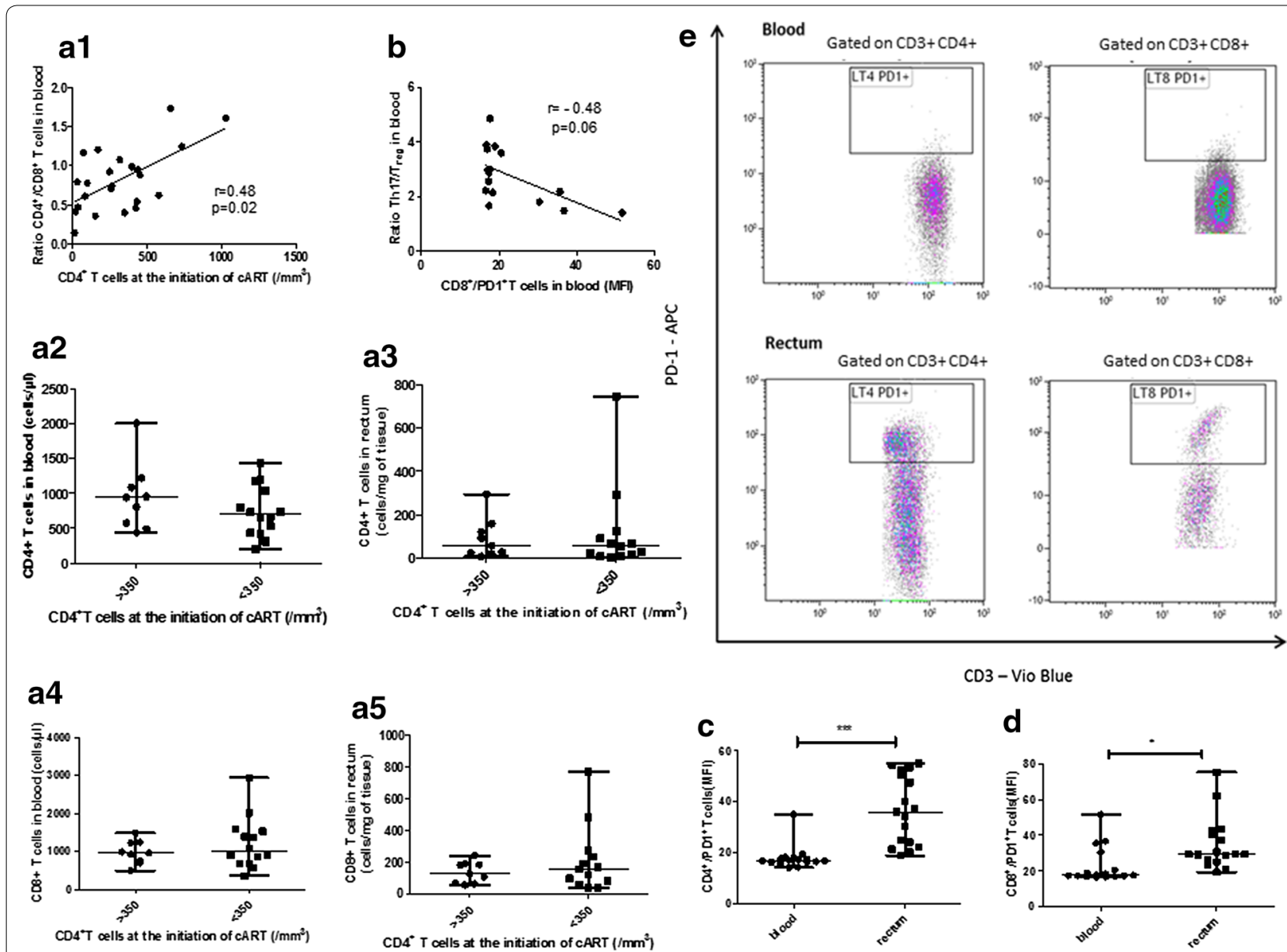

CD3 - Vio Blue

Fig. 1 Initiation of CART with higher CD4 level preserves CD4 ${ }^{+}$T cells in blood and exhaustion marker PD-1 reveals a defect of the gut barrier integrity. Correlation between $C D 4^{+} T$ cells at the initiation of CART and ratio $C D 4^{+} / C D 8^{+} T$ cells in blood $\left(\mathbf{a}_{\mathbf{1}}\right)$ or with absolute numbers of $C D 4^{+} T$ cells in blood $\left(\mathbf{a}_{\mathbf{2}}\right)$ and rectum $\left(\mathbf{a}_{\mathbf{3}}\right)$ or CD8 ${ }^{+} \mathrm{T}$ cells $\left(\mathbf{a}_{\mathbf{4}}, \mathbf{a}_{\mathbf{5}}\right)$. Correlation between PD-1 expression on CD8 ${ }^{+} \mathrm{T}$ cells $(\mathrm{MFI})$ in blood and Th17/Treg ratio in blood (b). Differences of PD-1 expression (MFI) in CD4 ${ }^{+}$and $C D 8^{+} \mathrm{T}$ cells in blood and rectum (c, d). Flow cytometry analysis of this marker in $\mathrm{CD} 4^{+}$and CD8 ${ }^{+} T$ cells $(\mathbf{e})$. Gating strategy: lymphoid cells were gated using the FSC/SSC parameters. Then, T cells were gated by their expression of CD3 and were separated in $\mathrm{CD}^{+}{ }^{+}$and $\mathrm{CD} 8^{+} \mathrm{T}$ cells by the $\mathrm{CD} 4$ expression and PD1 expression was studied in $\mathrm{CD}^{+} / \mathrm{CD}^{+}$and $\mathrm{CD} 3^{+} / \mathrm{CD}^{+}{ }^{+} \mathrm{T}$ cells. Horizontal lines represent median values and ranges. ${ }^{*} p<0.05 ;{ }^{* *} p<0.0001$. Each symbo/ represents an individual patient

higher in rectum (MFI CCR5 40.85 [37.9-45.91] in blood vs $52.64[44.4-70.3]$ in rectum, $\mathrm{p}=0.0006)$.

\section{A persistent imbalance of the Th17/Treg ratio is maintained despite a higher level of CD4 when initiating CART (Fig. 1 and Additional file 1: Figure S1)}

The Th17 cells/Treg ratio was not different between the two groups of patients in blood (2.9 [1.4-4.3] in "highlevel CD4 group" and 2.2 [1.5-3] in "low-level CD4 group", $\mathrm{p}=0.64)$ and in rectum $(1.4[1.1-2.8]$ in "highlevel CD4 group" and 1.3 [1.1-2.5] in "low-level CD4 group", $\mathrm{p}=0.96$ ). It tended to be associated to a lower exhaustion stage of $\mathrm{CD}^{+} \mathrm{T}$ cells in blood $(\mathrm{r}=-0.48$, $\mathrm{p}=0.06$; Fig. 1b).
Alterations in $\mathrm{B}^{+} \mathrm{CD} 4^{+} \mathrm{T}$ cells homing to the gut is higher in patients who started CART with low CD4 count (Fig. 2 and Additional file 3: Figure S3 and Additional file 4: Fig.

S4)

The blood/rectum ratio of $\beta 7^{+}$expression (MFI ratio from the gated $\mathrm{CD} 4^{+} / \beta 7^{+}$population) reflecting an approach to the alteration of gut homing, was calculated. It was significantly higher in patients who started the cART with low CD4 count (1.6 [1.3-1.8] vs 0.9 [0.8-1.2], $\mathrm{p}=0.006)$. An inverse correlation between the CD4 level at the time of CART initiation and the alteration of $\beta 7^{+} \mathrm{CD}^{+} \mathrm{T}$ cells homing to the gut $(\mathrm{r}=-0.8$, $\mathrm{p}=0.0003$ ) was observed (Fig. 2a). Nevertheless, there was no alteration of the gut homing of $\beta 7^{+} / \mathrm{CD} 8^{+} \mathrm{T}$ 


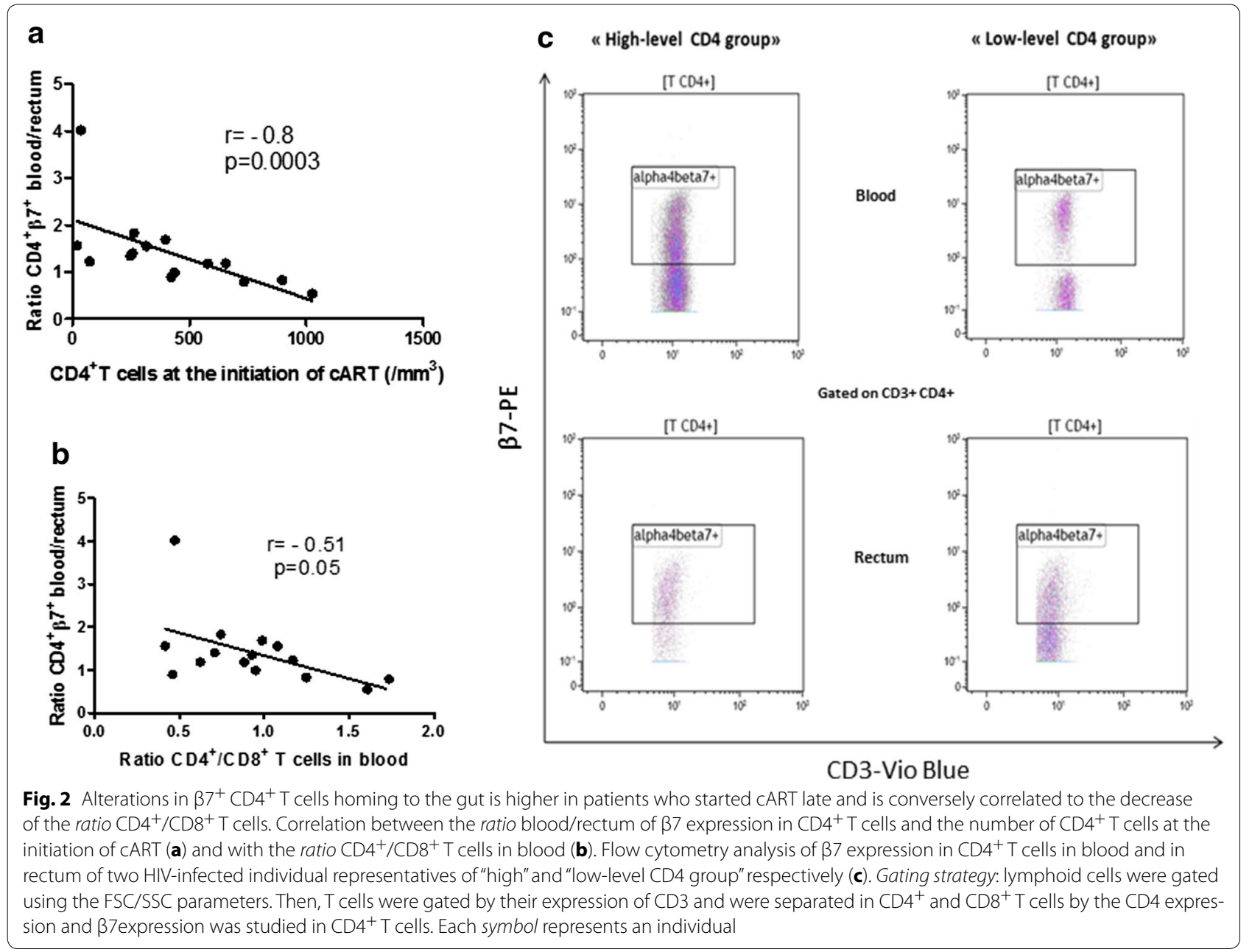

cells (ratio 0.7 in "high-level CD4 group" [0.5-1.2] vs 0.8 $[0.7-1]$ in "low-level CD4 group", $\mathrm{p}=0.54$ ). The alteration of homing to the gut could also be evaluated also by the ratio of $\beta 7$ expression in $\mathrm{CD}^{+} \mathrm{T}$ cells in blood and total $\mathrm{CD}^{+} \mathrm{T}$ cells in rectum but there was no difference between the two groups. The blood/rectum ratio of $\beta 7^{+} /$ $\mathrm{CD}^{+} \mathrm{T}$ cells was conversely associated with the ratio $\mathrm{CD}^{+} / \mathrm{CD}^{+} \mathrm{T}$ cells in the blood $(\mathrm{r}=-0.51, \mathrm{p}=0.05)$ (Fig. 2b) but not in the rectum $(r=0.14, p=0.61)$. CCR9 gut homing receptor was expressed equally in both compartments (gut and blood) in the two groups. Its expression in rectal $\mathrm{CD}^{+} \mathrm{T}$ cells was not significantly higher in "high-level CD4 group" (MFI 19.11 [16.41-26.14]) versus "low-level CD4 group" (MFI 16.36 [14.78-18.78]), $\mathrm{p}=0.12$. Overall, CCR9 expression in other subtypes (rectal and peripheral $\mathrm{CD} 4^{+} \mathrm{T}$ cells and peripheral $\mathrm{CD} 8^{+}$ $\mathrm{T}$ cells) was similar in the two groups of patients ( $\mathrm{p}>0.5$ ).

Among $\mathrm{CD} 4^{+} \mathrm{T}$ cells, no difference of distribution was observed in the subtypes of maturation according to the patient's group (naive in blood, $\mathrm{p}=0.36$, and in gut, $\mathrm{p}=0.73 ; \mathrm{CM}$ in blood, $\mathrm{p}=0.97$ and in gut, $\mathrm{p}=0.39 ; \mathrm{EM}$ in blood, $\mathrm{p}=0.55$ and in gut, $\mathrm{p}=0.49$; EMRA, $\mathrm{p}=0.22$ and in gut, $\mathrm{p}=0.66$ ).

\section{CD4 low count at the initiation of CART leads to an alteration of B cells maturation (Fig. 3 and Additional file 5: Figure S5)}

Proportion of non-conventional $\mathrm{CD}^{+} \mathrm{B}$ cells were not significantly different in rectum and blood (69.5 [66.277.8 ] vs 75.4 [71.5-83.9], $\mathrm{p}=0.06)$. Naive $\operatorname{IgD}^{+} \mathrm{B}$ cells were more represented in blood versus rectum $(79.01 \%$ of conventional B cells [75.61-85.79] vs $35.58 \%$ [24.3740.67], $\mathrm{p}<0.0001$ ) and were more frequent in blood of "low-level CD4" group patients (82.2 [77.3-87.6] vs $76.6 \%$ [60.6-79.1], $\mathrm{p}=0.05$ ) (Fig. 3a) and activated B cells $\mathrm{IgD}^{-}$were less represented $(17.6[12.4-22.4]$ vs $23.1 \%$ [20.8-38.8], $\mathrm{p}=0.05$ ). Proportion of $\operatorname{IgD}^{+}$naive $\mathrm{B}$ cells conversely correlated to the current $\mathrm{CD} 4^{+} / \mathrm{CD} 8^{+} \mathrm{T}$ cells ratio in blood $(r=-0.51, p=0.02$; Fig. $3 b)$. Distribution of memory $\mathrm{B}$ cells in blood was equivalent in the 


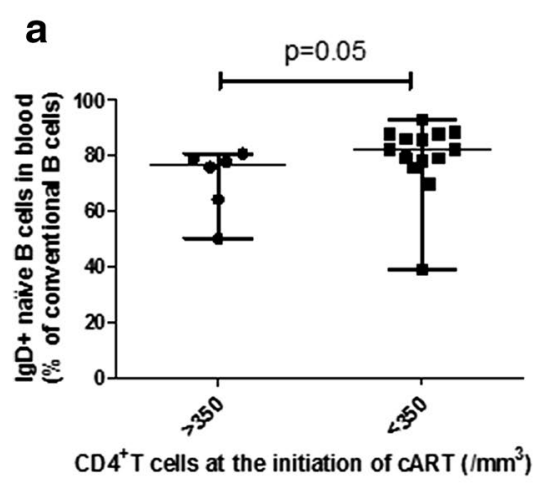

b

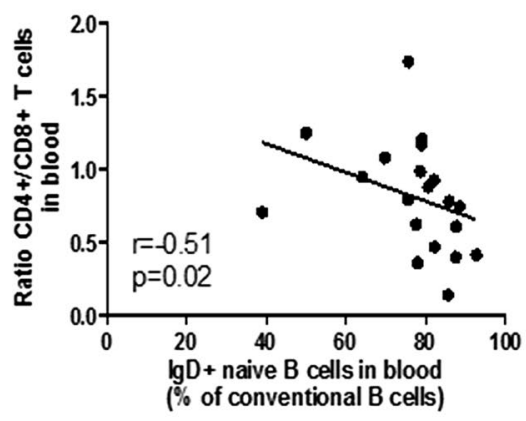

C «High-level CD4 group»

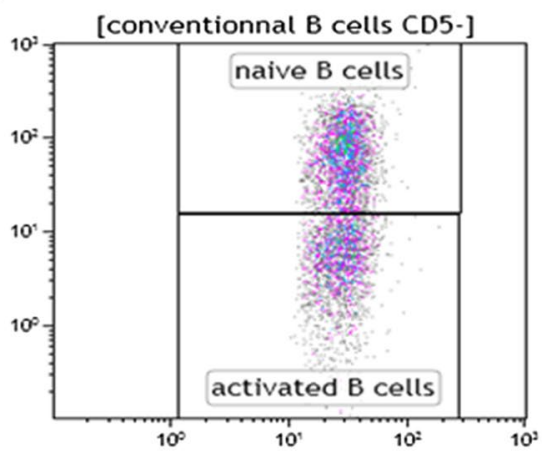

Gated on CD19+ CD5-

« Low-level CD4 group»

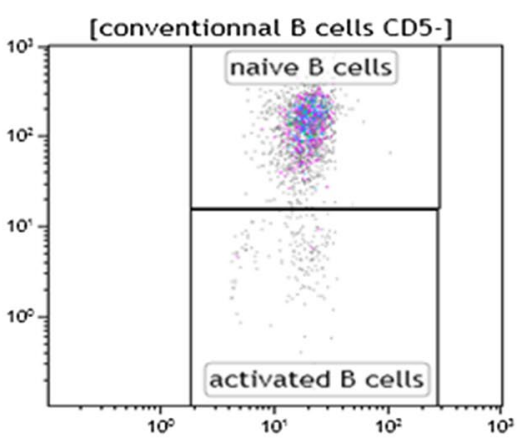

CD19-Vio Blue

Fig. 3 Repartition of naive and activated B cells in blood, according to the CD4 ${ }^{+} \mathrm{T}$ cells at the initiation of CART. Frequency of IgD ${ }^{+}$naive $B$ cells $(\mathbf{a})$ in blood of HIV-1 infected individuals, treated above or below $350 \mathrm{CD} 4^{+} / \mathrm{mm}^{3} \mathrm{~T}$ cells count. Horizontal lines represent median values and ranges. Correlation between current $\mathrm{CD}^{+} / \mathrm{CD} 8^{+} \mathrm{T}$ cells ratio in blood and percentage of lgD ${ }^{+}$naive $\mathrm{B}$ cells in blood of HIV infected individuals (b). Each symbol represents an individual. Flow cytometry analysis of $\operatorname{lgD}^{+} / \mathrm{CD} 19^{+} / \mathrm{CD}^{-}$B cells in the blood of two HIV-infected individual representatives of "high" and "low-level CD4 group" respectively (c). Gating strategy: lymphoid cells were gated using the FSC/SSC parameters. Then, B cells were gated by their expression of $\mathrm{CD} 19$ and were separated in $\mathrm{CD}^{+}$non-conventional and $\mathrm{CD}^{-}$conventional $\mathrm{B}$ cells. IgD expression was studied in $\mathrm{CD}^{-}$ conventional $B$ cells to plot naive and activated B cells

two groups $(5.94 \%$ of conventional B cells [1.68-18.05] in "high-level CD4 group" vs $4.05 \%$ [2.07-5.66] in "lowlevel CD4" group, $\mathrm{p}=0.34$ ). Contrary to $\mathrm{CD} 4^{+} \mathrm{T}$ cells, no increase of $\beta 7^{+}$B cells in blood of "low-level CD4" group was observed.

\section{Initiation of CART with high CD4 level results in a lower HIV-1 reservoir in blood and gut (Fig. 4)}

Total HIV DNA loads in blood and rectal compartments were correlated $(r=0.65, p=0.0008)$. The median HIV DNA load was not higher in rectum than in PBMCs (3.51 [2.81-3.96] vs 3.21 [2.44-3.65] log copies/millions of cells, $\mathrm{p}=0.24)$. HIV DNA loads were significantly higher in "low-level" than in "high-level CD4" group (3.48 [3.17-3.7] vs 2.41 [2.03-2.93] log copies/millions of cells, $\mathrm{p}=0.002$ and $3.6[3.4-4.08]$ vs $3.06[1.93-3.63]$ $\log$ copies/millions of cells, $\mathrm{p}=0.042$ in blood and rectum, respectively, Fig. 4c, d). An inverse correlation between the number of blood $\mathrm{CD} 4^{+} \mathrm{T}$ cells at the time of cART initiation and the size of HIV reservoir in blood $(r=-0.52, p=0.01)$ but not in rectum $(r=-0.3$, $\mathrm{p}=0.15$ ) was observed (Fig. $4 \mathrm{~b}$ ). The patients who initiated cART during PHI presented a lower size of HIV reservoir in blood and rectum. The presence of HIV RNA was detected in 15 out of 24 (62.5\%) PBMCs and in 21 out of $24(87.5 \%)$ rectal biopsies, respectively. HIV-1 DNA levels were significantly higher in rectum of patients exhibiting detectable HIV-1 RNA in this compartment (3.59 [3.34-3.99] vs 1.4 [0.85-1.76], $\mathrm{p}=0.008$ ). This was not verified in blood compartment, but the expression of p24 in $\mathrm{CD}^{+} \mathrm{T}$ cells in PBMC tended to be higher when the virus was detected in periphery $(1.03[0.57-1.82]$ vs 

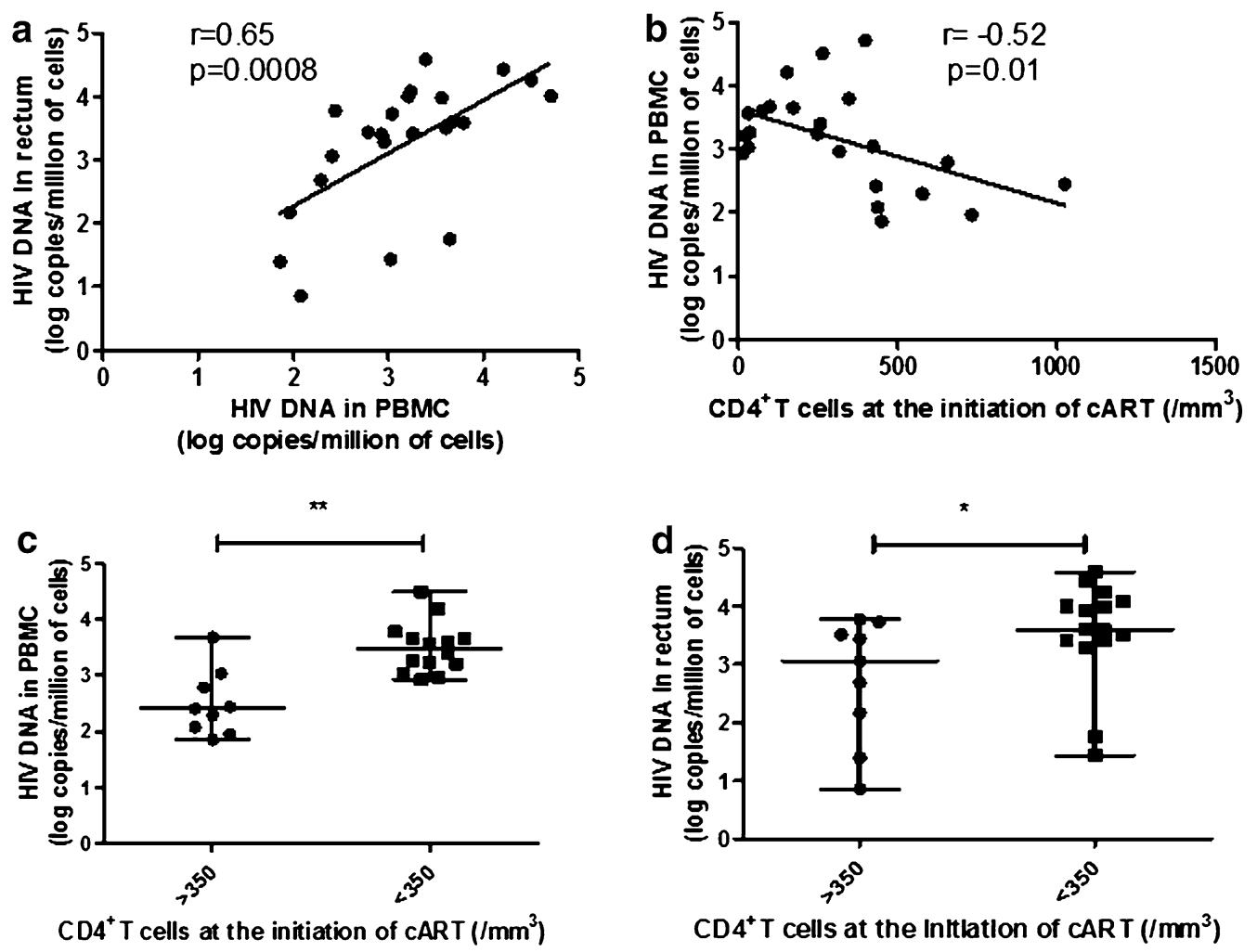

Fig. 4 HIV reservoir size is lower in blood and rectum of patients who initiated CART with low number of CD4 ${ }^{+} T$ cells. Correlation between HIV DNA loads in PBMC and rectum (a). Correlation between HIV DNA in PBMC and number of CD4 ${ }^{+} T$ cells at the initiation of cART (b). Comparison between HIV DNA loads in PBMC (c) and rectum (d) of patients from the two groups. HIV DNA loads are expressed in log copies/million of cells. Horizontal lines represent median values and ranges. ${ }^{*} p<0.05 ;{ }^{* *} p<0.01$. Each symbol represents an individual

$0.39 \%$ of $\mathrm{CD}^{+}{ }^{+} \mathrm{T}$ cells [0.34-0.8], $\left.\mathrm{p}=0.09\right)$. No significant relation was observed between HIV-1 RNA detection and the ratio $\mathrm{CD} 4^{+} / \mathrm{CD} 8^{+} \mathrm{T}$ cells, Th17/Treg ratio, $\beta 7 \mathrm{blood} /$ rectum ratio, and PD1 ${ }^{+}$expression in T cells, in both compartments.

\section{Discussion}

The $\mathrm{CD} 4^{+} \mathrm{T}$ cells subset depletion is higher in gut than in peripheral compartment and its recovery is delayed and incomplete under cART [5]. In our study, we showed that the ratio $\mathrm{CD} 4^{+} / \mathrm{CD}^{+} \mathrm{T}$ cells was higher in the blood than in the rectum of cART-experienced patients and was correlated to the CD4 count at the time of initiation of therapy. A persistent activated and exhausted phenotype of PD-1 expressing T cells in GALT has been evidenced, independently of the CD4 level measured at the time of cART initiation. The role of PD-1 is defined as a negative regulator of $\mathrm{T}$ cell function during HIV infection, and thus as an indicator of immune activation and disease progression. It contributes to the generation of activated $\mathrm{T}$ cell targets for the virus itself, further driving viral replication $[28,29]$.
A persistent immune activation in GALT promotes early and serious immunological and structural injuries of the mucosal barrier favoring the translocation of microbial products, such as LPS, into the systemic circulation $[30,31]$. Th17 cells represent a $\mathrm{CD} 4^{+} \mathrm{T}$ cells subset involved in enterocytes homeostasis, that plays a critical role in the mucosal defense against bacteria and fungi. Those cells are preferentially depleted in the GALT of HIV-infected patients [6]. The median counts of Th17 cells were similar in the blood and in the rectum in our two studied groups. The role of Th17 cells is balanced by Treg cells and the Th17/Treg ratio reflects the gut homeostasis preservation. In our study, as in others, the gut homeostasis was not significantly improved in the "high-level CD4 group", and despite several years of cART, the restoration of $\mathrm{CD}^{+}$and Th17 cells remains typically incomplete, even in the four men who started cART during PHI [4, 32-34]. This finding is not in agreement with a previous study demonstrating a preservation of mucosal Th17 function in gut of patients who had initiated cART very early. This can be due to differences between the two studied populations, in terms 
of size (low in our work) and Fiebig stage at the time of cART start (FIII vs F I/II) [27]. Interestingly, in our study, gut homeostasis was negatively correlated with $\mathrm{CD}^{+}$ $\mathrm{T}$ cell exhaustion. This could participate to increase the immune activation, probably contributing to the vicious circle "immune activation-viral replication and depletion of activated target T cells-microbial translocation".

Another hypothesis to explain the impairment of the ratio $\mathrm{CD}^{+} / \mathrm{CD}^{+} \mathrm{T}$ cells of GALT under cART is the alteration of $\mathrm{CD} 4^{+} \mathrm{T}$ cell homing to the gut. The $\alpha 4 \beta 7$ integrin is involved in gut homing of $\mathrm{T}$ cells via the Mucosal vascular-Addressin Cell-Adhesin Molecule 1 (MAdCAM-1) expressed on endothelial cells in gut. The ability of HIV-1 gp120 to bind to and signal through $\alpha 4 \beta 7$ could contribute to the tropism of HIV- 1 for $\mathrm{CD} 4^{+} \mathrm{T}$ cells in the gut $[3,35]$. As previously reported, $\alpha 4 \beta 7^{+} \mathrm{CD} 4^{+} \mathrm{T}$ cells could be distinguished by high-level expression of integrin $\beta 7$ [35]. In our study, the blood/rectum $\mathrm{CD} 4^{+} \beta 7^{+}$ cells ratio reflects the alteration of gut homing $\mathrm{CD} 4^{+} \mathrm{T}$ cells. A later initiation of cART is significantly associated with a major gut homing alteration of $\mathrm{CD} 4^{+}$, but not of other lymphocytes subsets (CD8 ${ }^{+} \mathrm{T}, \mathrm{B}$ lymphocytes). We could hypothesize that this homing defect contributes to the $\mathrm{CD}^{+} \mathrm{T}$ cells deficiency in GALT. Nevertheless, this defect of homing was not significantly correlated with the decrease of the ratio $\mathrm{CD} 4^{+} / \mathrm{CD} 8^{+} \mathrm{T}$ cells in rectum. This may be explained by the moderate number of patients in our study and by a probable peripheral $\alpha 4 \beta 7$ up-regulation. Mavigner et al. suggested that many of the CCR9/ $\alpha 4 \beta 7$ expressing-CD $4^{+} \mathrm{T}$ cells remained in the blood circulation rather than repopulating the gut mucosa because of a lower expression of the CCL25 CCR9 ligand in the intestine of HIV-infected individuals, whereas the MAdCAM-1 expression was similar in HIV-infected patients and healthy controls [5]. We did not confirm the data of a recent paper reporting an absence of depletion of $\mathrm{CD}^{+}{ }^{+}$cells expressing gut homing markers, in blood and in gut of cART-experienced patients [36]. However, the two works are difficult to compare since studied populations, particularly in terms of durations of infection and CART therapy, and methods (cells isolation, lymphocytes subpopulations studied) are slightly different. Interestingly, it has been suggested that the expression of $\alpha 4 \beta 7$ and CCR9 on activated T cells is stimulated by retinoic acid, a vitamin A metabolite produced by dendritic cells [37]. Quantifying this marker in blood could be helpful to evaluate the GALT homing ability of T cells.

As previously described, B cells hyperactivation by HIV is a common feature, characterized by hypergammaglobulinemia and a rapid turnover [16]. These abnormalities are generally reversed by cART, excepting the loss of memory B cells. However, it was suggested that an early cART initiation could partially reverse the low frequency of $\operatorname{IgM}^{+}$memory B cells [38]. A similar tendency with a higher percentage of $\operatorname{IgM}^{+}$memory B cells in the blood of patients treated with higher CD4 count was also noticed. Another interesting result concerns an expansion of naive B cells in the blood of our "low-level $\mathrm{CD} 4$ group", to the detriment of mature B cells, very likely related to the T-cells cooperation defect in "low-level $\mathrm{CD} 4$ group". A low number of $\mathrm{CD} 4^{+} \mathrm{T}$ cells was correlated to an expansion of naive $B$ cells, that could lead to a production of low-specific antibodies and paucity of HIV-specific IgA response at mucosal sites [38].

One of the major obstacle to HIV eradication is the persistence of virus within infected $\mathrm{CD} 4^{+} \mathrm{T}$ cells in GALT and other reservoirs [39-41]. In our study, HIV DNA was detected and quantified in the rectum of all the 24 participants and for 21 of them, a persistent viral replication was detected, despite a controlled viraemia, as previously reported [42-44]. We found that patients who started cART early (during the PHI phase) exhibited a lower-size of viral reservoir in GALT and in PBMC, as previously demonstrated [17]. In PTc VISCONTI cohort, the benefit of an early treatment on the size of HIV reservoir was demonstrated [21]. Similarly, we found a significant lower HIV DNA gut reservoir in the group of men who started cART with a CD4 cells count over $350 / \mathrm{mm}^{3}$. In our study, a low size of viral reservoir was not significantly associated to the increase of the ratio $\mathrm{CD} 4^{+} / \mathrm{CD} 8^{+} \mathrm{T}$ cells or to a loss of immune activation. The limited size of our population could explain that but Hey-Cunningham et al. reported the same findings in patients treated by HIV integrase inhibitors [45]. Without cART, «elite controllers» have abnormal levels of $\mathrm{T}$ cell activation despite maintaining undetectable viral loads, explained by HLA polymorphisms leading to stronger innate immune responses or lower regulatory $\mathrm{T}$ cell activity against HIV infection, both factors that might contribute to more-potent suppression of HIV replication [46]. Moreover, a persistent residual viraemia was reported in patients under suppressive cART, but the question whether it represents an active replication or the release of non-productive virus from the reservoir has not been resolved [47]. In our study, the hypothesis of an active replication could be suggested by the existence of a higher rectal reservoir in patients with detectable HIV RNA in gut. To better appreciate the size of the reservoir and the latent or the replicative state of the virus it would have been interesting to quantify the integrated and 2LTR forms of the virus in peripheral blood and tissues.

There are several limitations in our study, concerning first its low statistical power due to the limited number of patients included, especially those treated at PHI stage. Moreover, it would have been very informative to assess 
the evolution of the viral rectal reservoir in men during the course of HIV infection, before and after cART initiation. Obviously, for ethical reasons it was not possible to obtain sequential biopsies in HIV infected men. Another important point is the time between infection and HIV diagnosis that is most of the time unknown but can influence the composition of the reservoir.

And finally, our study aims to explore the rectal reservoir and it is admitted that the distribution of HIV DNA and RNA in cell subsets differs in different gut compartments. This might be kept in mind when interpreting the results but an exhaustive analysis is quite complicated, since the gastrointestinal tissues are not easily accessible.

\section{Conclusions}

In conclusion, our study suggests that early treatment partially circumvents immune dysregulation in the rectum of HIV-infected men even if their $\mathrm{CD} 4^{+}$cell count was elevated at the time of initiation of therapy. These findings confirm the great interest of an initiation of cART in the early stages of HIV infection to limit the viral reservoir constitution, to preserve the gut immunity and, as a consequence, to improve patients outcomes and reduce HIV transmission at the population level.

\section{Methods}

\section{Patients and samples}

HIV-1 chronically infected consenting men followed at the Infectious Diseases Department of the University Hospital of Saint-Etienne were enrolled. They had been under CART for more than one but $<5$ years, without any viral escape during this period. They also had an indication for anal cancer screening by rectoscopy. For each patient, 2 EDTA-blood samples and 4 rectal biopsies were collected at the Gastroenterology Unit of the University Hospital of Saint-Etienne. Patients were distributed in 3 groups concerning the stage of infection at the time of diagnosis, according to the CDC Classification System for HIV Infection: A (Asymptomatic or Acute HIV Infection), B (Symptomatic conditions), C (AIDSIndicator conditions). The patient characteristics are summarized in Table 2.

\section{Tissues and cells preparation (Additional file 6: Figure S6)}

PBMC were isolated from whole blood samples by standard density gradient centrifugation (Lymphoprep, AxisShield, Oslo, Norway), numbered and about 1 million of cells were stored at $-80{ }^{\circ} \mathrm{C}$ until use. An immunophenotypical analysis was realized on the remaining fresh blood cells. Two out of four rectal biopsies were immediately frozen at $-80{ }^{\circ} \mathrm{C}$ until molecular biology testing. The remaining fresh biopsies were dedicated to the immunophenotypical analysis and were first incubated in RPMI 1640 (PAA, Pasching, Austria), supplemented with $1 \%$ of antibiotics (penicillin $100 \mathrm{U} / \mathrm{ml}$ and streptomycin $100 \mu \mathrm{g} / \mathrm{ml}$, PAA) and $10 \%$ of fetal bovine serum (Sigma Aldrich, Saint-Louis, USA). Biopsies were then crushed immediately with a sterile scalpel and a medicon of $50 \mu \mathrm{m}$ (BD Biosciences, San Jose, USA) and $1 \mathrm{ml}$ of EDTA/Versene solution (Gibco Life technologies, Paisley, UK) was added to the cellular suspension to avoid aggregates. A mechanical disruption and a filtration of the suspension were performed with a syringe equipped with a 30-gauge blunt-end needle (Nipro Europe, Zaventem, Belgium) and a sterile filter of $30 \mu \mathrm{m}$ (BD Biosciences). Then, rectal cells were washed with RPMI-FCS and resuspended in that medium. The quantity of cells was determined by the automated cell counter TC10 (Biorad, Hercules, CA, USA), and the viability was estimated by a trypan blue labelling.

\section{Immunophenotypical analysis}

For each patient, an extensive immunophenotypical analysis of blood and rectal fresh cells was performed. $\mathrm{T}$ cells were stained with anti-CD3/VioBlue (BW264/56), anti-CD4/Viogreen (VIT4), anti-CD8/APC-Cyanine7 (BW135/80) (Miltenyi Biotec, Bergisch Gladbach, Germany). The $\mathrm{CD}^{+} \mathrm{T}$ cells/CD8 ${ }^{+} \mathrm{T}$ cells ratio was used to explore the immune dysregulation. Among $\mathrm{T}$ cells, regulatory cells were identified as CD25 $5^{\text {high }}$ (anti-CD25/ PC7, B1.49.9, Iotest Beckman Coulter, Brea, USA) and CD127 ${ }^{\text {low }}$ (anti-CD127/FITC, MB15-18C9, Miltenyi Biotec) [48]. The CCR6 (anti-CD196/APC, 11A9, BD Biosciences) and the CD45 RA (CD45RA/PC7, 2H4LDH11LDB9, Iotest Beckman Coulter) markers were used to characterize Th17 cells $[5,49-51]$. The Th17 population was defined as $\mathrm{CD} 4^{+} / \mathrm{CD} 4 \mathrm{RA}{ }^{-} / \mathrm{CCR}^{+}$. The Th17/ Treg ratio was calculated. The expression of $\beta 7$ integrin and CCR9 homing intestinal markers was studied on $\mathrm{T}$ and/or B cells (anti- $\beta 7 / \mathrm{PE}$, FIB504 and anti-CDw199/ APC, 112509, BD Biosciences) [5]. Different states of T cells maturation were characterized by anti-CD45RA/ PC7 and CCR7 (anti-CD197/FITC, 150503, BD Biosciences): naive $\left(\mathrm{CD} 45-\mathrm{RA}^{+} / \mathrm{CCR} 7^{+}\right)$, central memory $\left(\mathrm{CM}, \mathrm{CD} 45-\mathrm{RA}^{-} / \mathrm{CCR}^{+}\right)$, effector memory (EM, CD45$\left.\mathrm{RA}^{-} / \mathrm{CCR}^{-}\right) \mathrm{T}$ cells and terminal effector cells expressing RA (EMRA, CD45-RA ${ }^{+} / \mathrm{CCR} 7^{-}$) [52, 53]. Exhausted and HIV-1 infected T cells were determined with PD-1 (anti-CD279/APC, MIH4, BD Biosciences) and intracellular HIV-p24 protein expression (anti-p24/FITC, 24-4, Santa Cruz Biotechnology), respectively [54, 55]. P24 antigen staining required a permeabilization stage (BD Cytofix/Cytoperm, BD Biosciences). HIV co-receptors CXCR4 (anti-CD184/PerCP-Cy5.5, 12 G5 CXCR4, BD Biosciences) and CCR5 (anti-CD195/APC-Cy7, 2D7/ CCR5, BD Biosciences) were also studied. 
Table 2 Comparison of the main characteristics of HIV infected-men enrolled in the study according to their CD4 ${ }^{+}$cells count at the time of CART initiation

Blood CD4 ${ }^{+} \mathrm{T}$ count at the time of diagnosis (cells $/ \mathrm{mm}^{3}$ )

p value

$>350$ “high-level CD4 group" $(n=9)<350$ “low-level CD4 group” $(n=15)$

\begin{tabular}{|c|c|c|c|}
\hline \multicolumn{4}{|l|}{ At the time of diagnosis } \\
\hline \multicolumn{4}{|l|}{ Route of contamination (\%) } \\
\hline MSM or bisexual & 100 & 86.7 & 0.51 \\
\hline Heterosexual & 0 & 13.3 & 0.51 \\
\hline \multicolumn{4}{|l|}{ Stage CDC of HIV infection (\%) } \\
\hline $\mathrm{A}(\mathrm{PHI})$ & 62.5 & 6.7 & 0.01 \\
\hline$B$ or $C$ & 0 & 40 & 0.05 \\
\hline \multicolumn{4}{|l|}{ At the time of blood and biopsy sampling } \\
\hline Age, median in years [range] & $48[28.5-49.5]$ & $53[46-61]$ & 0.03 \\
\hline $\begin{array}{l}\text { Time since diagnosis of HIV infection, median in months } \\
\text { [range] }\end{array}$ & $40[27.5-105.5]$ & $44[26-48]$ & 0.63 \\
\hline Total time on CART, median in months [range] & $34[18.5-60]$ & $42[24-46]$ & 0.68 \\
\hline \multicolumn{4}{|l|}{ CART regimen (\%) } \\
\hline $3 N R T I$ & 100 & 93.3 & 0.009 \\
\hline $2 \mathrm{NRTI} / 1 \mathrm{NNRTI}$ & 55.5 & 53.3 & 1 \\
\hline 2NRTI/1 PI & 44.4 & 46.6 & 1 \\
\hline 2 NRTI/1 II & 0 & 13.3 & 0.51 \\
\hline \multicolumn{4}{|l|}{ At the time of CART initiation } \\
\hline $\begin{array}{l}\text { Time since diagnosis of HIV infection, median in months } \\
\text { [range] }\end{array}$ & $2[0.5-73.5]$ & $0[0-1]$ & 0.05 \\
\hline Initiation at PHI stage (\%) & 33.3 & 6.7 & 0.13 \\
\hline $\mathrm{CD}^{+}{ }^{+} \mathrm{T}$ cells $/ \mathrm{mm}^{3}$, median [range] & 450 [427-695] & 98 [31-257] & $<0.0001$ \\
\hline PVL in $\log _{10}$ copies/ml, median [range] & $4.97[4.24-6.1]$ & $5.52[5.17-5.94]$ & 0.25 \\
\hline
\end{tabular}

CART combined antiretroviral therapy, CDC centers for disease control and prevention, Il integrase inhibitors, PHI primary HIV infection, $P V L$ plasmatic viral load, NNRTI non-nucleoside reverse transcriptase inhibitors, NRTI nucleoside reverse transcriptase inhibitors, PI protease inhibitors

B cells were stained with anti-CD19/VioBlue (HD37, DakoCytomation, Denmark) and anti-CD5/PC7 (BL1a, Iotest Beckman-Coulter) to distinguish conventional and non-conventional B cells. The phenotype of maturation was evaluated with anti-IgD/FITC (IADB6, Iotest Beckman Coulter), anti-IgM/APC (G20-127, BD Biosciences), anti-CD27/APC-Cy7 (M-T271, BD Biosciences) [56, 57]. Naïve (unswitched) $\left(\mathrm{CD}_{1} 9^{+} / \mathrm{IgD}^{+}\right)$, unswitched memory $\left(\mathrm{CD} 19^{+} / \mathrm{IgM}^{+} / \mathrm{CD} 27^{+}\right)$and activated (switched) $\left(\mathrm{CD}_{19}{ }^{+} / \mathrm{IgD}^{-}\right) \mathrm{B}$ cells were compared.

\section{Flow cytometry analysis}

Analyses were performed on a FACS Canto II (Becton-Dickinson, Franklin Lakes, NJ, USA) and data were analyzed using Kaluza software (Version 1.3, BeckmanCoulter, Brea, USA). Lymphocytes were examined using forward/side-scatter gating. T cells and B cells were identified subsequently as $\mathrm{CD}^{+}$and $\mathrm{CD} 19^{+}$cells, within the lymphocytes population. Each tube was run until 50,000 events were recorded or the tube was exhausted. Our gating strategy was based on fluorescence minus one technique (FMO) to determine the positivity in expression of each considered surface marker.

\section{Total cell-associated HIV-1 DNA quantification}

Total DNA was extracted from PBMCs and biopsies using the QIAamp DNA Mini Kit (Qiagen, Courtaboeuf, France). The cell-associated HIV-1 DNA was quantified by using Generic HIV ${ }^{\circledR}$ DNA cell protocol (Biocentric, Bandol, France) according to the manufacturer's instructions. The quantification of the glyceraldehyde-3-phosphate dehydrogenase (GAPDH) gene was undertaken to estimate the amount of cells tested. The results were expressed in a log of HIV DNA copies per million of cells.

\section{Intra-cellular HIV-1 RNA detection}

Total RNA was extracted from PBMCs and biopsies using RNA Blood Mini Kit (Qiagen) and RNeasy (Qiagen), respectively. HIV-1 RNA was detected by real-time PCR using the Generic HIV ${ }^{\circledR}$ assays (Biocentric), according to manufacturer's instructions. 


\section{Statistical analysis}

Statistical analysis was performed using Prism GraphPad version 5 Software (GraphPad Prism, San Diego, CA, USA). Medians and interquartile ranges (IQR) were used to represent the average values. The non-parametric Mann-Whitney test and Chi-square test were used to determine the significance of differences between the two groups. The correlation between the level of $\mathrm{CD} 4^{+}$ $\mathrm{T}$ cells at the beginning of cART and the immunological and virological characteristics of reservoirs was analyzed using the Spearman correlation test. A p value $<0.05$ was considered to be statistically significant.

\section{Additional files}

Additional file 1: Figure S1. Correlation between $\mathrm{CD} 4^{+} \mathrm{T}$ cells at the initiation of $C A R T$ and $C D 4^{+} / C D 8^{+} T$ cells ratio in rectum (A). Intensity of PD-1 expression in blood (B) and rectum (C), Th17/Treg ratio in blood (D) and rectum (E) of patients according to their group. Horizontal lines represent median values and ranges. Each symbol represents an individual. NS: Non-Significant.

Additional file 2: Figure S2. Representation of the gating strategy of $\mathrm{PD}^{+} / \mathrm{CD}^{+}$and $\mathrm{PD} 1^{+} / \mathrm{CD}^{+} \mathrm{T}$ cells. Example in the blood of a patient from the "high-level CD4 group".

Additional file 3: Figure S3. Representation of the gating strategy of beta $7^{+} / \mathrm{CD}^{+}$and beta $7^{+} / \mathrm{CD} 4^{-} \mathrm{T}$ cells. Example in the blood of a patient from the "low-level CD4 group".

Additional file 4: Figure S4. Correlation between $\mathrm{CD} 4^{+} / \mathrm{CD} 8^{+} \mathrm{T}$ cells ratio in rectum and $\beta 7 C D 4^{+} T$ cells blood/rectum ratio (A) or between $\mathrm{CD}^{+} / \mathrm{CD}^{+} \mathrm{T}$ cells ratio in blood and intensity of $\beta 7$ expression in $\mathrm{CD}^{+} \mathrm{T}$ cells in blood (B). Each symbol represents an individual.

Additional file 5: Figure S5. Representation of the gating strategy of naive and activated conventional B cells. Example in the blood of a patient from the "low-level CD4 group".

Additional file 6: Figure S6. Design of the Virect study.

\section{Authors' contributions}

ADB performed molecular and immunological experiments and wrote the manuscript; DVM and AG performed molecular and immunological experiments; AF, EBN and FL participated to the inclusion of patients, collected clinical and therapeutical information's and corrected the manuscript; $\mathrm{CL}$ supervised and interpreted data obtained by flow cytometry; BP supervised the virological data and corrected the manuscript; CG supervised the immunological data; EDT included patients and performed the rectal biopsies; XR included patients, performed the biopsies and corrected the manuscript; TB and SP designed the study and wrote the manuscript. All authors read and approved the final manuscript.

\section{Author details}

${ }^{1}$ Groupe Immunité des Muqueuses et Agents Pathogènes - GIMAP EA 3064, CIC 1408, Faculté de Médecine J. Lisfranc, Université de Saint-Etienne, Université de Lyon, 42023 Saint-Étienne Cedex 02, France. ${ }^{2}$ Laboratoire d'Immunologie, Centre Hospitalo-Universitaire, Saint-Étienne, France. ${ }^{3}$ Service de Maladies Infectieuses et Tropicales, Centre Hospitalo-Universitaire, Saint-Étienne, France. ${ }^{4}$ Service d'Hépato-Gastroentérologie, Centre Hospitalo-Universitaire, Saint-Étienne, France. ${ }^{5}$ Service des Agents Infectieux et d'Hygiène, Centre Hospitalo-Universitaire, Saint-Étienne, France.

\section{Acknowledgements}

This work was partially supported by research Grants from ANRS and Sidaction.

\section{Competing interests}

The authors declare that they have no competing interests.

Received: 7 April 2016 Accepted: 20 June 2016

Published online: 30 June 2016

\section{References}

1. Brenchley JM, Schacker TW, Ruff LE, Price DA, Taylor JH, Beilman GJ, Nguyen PL, Khoruts A, Larson M, Haase AT, Douek DC. CD4 ${ }^{+}$T cell depletion during all stages of HIV disease occurs predominantly in the gastrointestinal tract. J Exp Med. 2004;200:749-59.

2. Poles MA, Elliott J, Taing P, Anton PA, Chen IS. A preponderance of CCR5(+) CXCR4(+) mononuclear cells enhances gastrointestinal mucosal susceptibility to human immunodeficiency virus type 1 infection. J Virol. 2001;75:8390-9.

3. Arthos J, Cicala C, Martinelli E, Macleod K, Van Ryk D, Wei D, Xiao Z, Veenstra TD, Conrad TP, Lempicki RA, McLaughlin S, Pascuccio M, Gopaul R, McNally J, Cruz CC, Censoplano N, Chung E, Reitano KN, Kottilil S, Goode DJ, Fauci AS. HIV-1 envelope protein binds to and signals through integrin $a 4 \beta 7$, the gut mucosal homing receptor for peripheral T cells. Nat Immunol. 2008;9:301-9.

4. Guadalupe M, Reay E, Sankaran S, Prindiville T, Flamm J, McNeil A, Dandekar S. Severe CD4 ${ }^{+}$T-cell depletion in gut lymphoid tissue during primary human immunodeficiency virus type 1 infection and substantial delay in restoration following highly active antiretroviral therapy. J Virol. 2003;77:11708-17.

5. Mavigner M, Cazabat M, Dubois M, L'Faqihi F-E, Requena M, Pasquier C, Klopp P, Amar J, Alric L, Barange K, Vinel J-P, Marchou B, Massip P, Izopet J, Delobel P. Altered CD4 ${ }^{+} \mathrm{T}$ cell homing to the gut impairs mucosal immune reconstitution in treated HIV-infected individuals. J Clin Investig. 2012;122:62-9.

6. Klatt NR, Brenchley JM. Th17 cell dynamics in HIV infection. Curr Opin HIV AIDS. 2010;5:135-40.

7. Epple H-J, Schneider T, Troeger H, Kunkel D, Allers K, Moos V, Amasheh M, Loddenkemper C, Fromm M, Zeitz M, Schulzke J-D. Impairment of the intestinal barrier is evident in untreated but absent in suppressively treated HIV-infected patients. Gut. 2009;58:220-7.

8. Favre D, Lederer S, Kanwar B, Ma Z-M, Proll S, Kasakow Z, Mold J, Swainson L, Barbour JD, Baskin CR, Palermo R, Pandrea I, Miller CJ, Katze MG, McCune JM. Critical loss of the balance between Th17 and T regulatory cell populations in pathogenic SIV infection. PLoS Pathog. 2009:5:e1000295

9. Shaw JM, Hunt PW, Critchfield JW, McConnell DH, Garcia JC, Pollard RB, Somsouk M, Deeks SG, Shacklett BL. Increased frequency of regulatory T cells accompanies increased immune activation in rectal mucosae of HIV-positive noncontrollers. J Virol. 2011;85:11422-34.

10. Marchetti G, Tincati C, Silvestri G. Microbial translocation in the pathogenesis of HIV infection and AIDS. Clin Microbiol Rev. 2013;26:2-18.

11. Douek D. HIV disease progression: immune activation, microbes, and a leaky gut. Top HIV Med Publ Int AIDS Soc USA. 2007;15:114-7.

12. Douek DC. Immune activation, HIV persistence, and the cure. Top Antivir Med. 2013;21:128-32.

13. Douek DC, Roederer M, Koup RA. Emerging concepts in the immunopathogenesis of AIDS. Annu Rev Med. 2009;60:471-84.

14. Douek DC, Picker LJ, Koup RA. T cell dynamics in HIV-1 infection. Annu Rev Immunol. 2003;21:265-304.

15. Titanji K, De Milito A, Cagigi A, Thorstensson R, Grützmeier S, Atlas A, Hejdeman B, Kroon FP, Lopalco L, Nilsson A, Chiodi F. Loss of memory B cells impairs maintenance of long-term serologic memory during HIV-1 infection. Blood. 2006;108:1580-7.

16. Moir S, Fauci AS. B cells in HIV infection and disease. Nat Rev Immunol. 2009;9:235-45

17. Jain V, Hartogensis W, Bacchetti P, Hunt PW, Hatano H, Sinclair E, Epling L, Lee T-H, Busch MP, McCune JM, Pilcher CD, Hecht FM, Deeks SG. Antiretroviral therapy initiated within 6 months of HIV infection is associated with lower T-cell activation and smaller HIV reservoir size. J Infect Dis. 2013;208:1202-11. 
18. Buzon MJ, Martin-Gayo E, Pereyra F, Ouyang Z, Sun H, Li JZ, Piovoso M, Shaw A, Dalmau J, Zangger N, Martinez-Picado J, Zurakowski R, Yu XG, Telenti A, Walker BD, Rosenberg ES, Lichterfeld M. Long-term antiretroviral treatment initiated at primary HIV-1 infection affects the size, composition, and decay kinetics of the reservoir of HIV-1-infected CD4 T cells. J Virol. 2014;88:10056-65

19. Hocqueloux L, Avettand-Fènoël V, Jacquot S, Prazuck T, Legac E, Mélard A, Niang M, Mille C, Le Moal G, Viard J-P, Rouzioux C. AC32 (Coordinated Action on HIV Reservoirs) of the Agence Nationale de Recherches sur le Sida et les Hépatites Virales (ANRS): long-term antiretroviral therapy initiated during primary HIV-1 infection is key to achieving both low HIV reservoirs and normal T cell counts. J Antimicrob Chemother. 2013;68:1169-78.

20. Evering TH, Mehandru S, Racz P, Tenner-Racz K, Poles MA, Figueroa A, Mohri H, Markowitz M. Absence of HIV-1 evolution in the gut-associated lymphoid tissue from patients on combination antiviral therapy initiated during primary infection. PLoS Pathog. 2012;8:e1002506.

21. Sáez-Cirión A, Bacchus C, Hocqueloux L, Avettand-Fenoel V, Girault I, Lecuroux C, Potard V, Versmisse P, Melard A, Prazuck T, Descours B, Guergnon J, Viard J-P, Boufassa F, Lambotte O, Goujard C, Meyer L, Costagliola D, Venet A, Pancino G, Autran B, Rouzioux C. ANRS VISCONTI Study Group: post-treatment HIV-1 controllers with a long-term virological remission after the interruption of early initiated antiretroviral therapy ANRS VISCONTI Study. PLoS Pathog. 2013;9:e1003211.

22. Whitney JB, Hill AL, Sanisetty S, Penaloza-MacMaster P, Liu J, Shetty M, Parenteau L, Cabral C, Shields J, Blackmore S, Smith JY, Brinkman AL, Peter LE, Mathew SI, Smith KM, Borducchi EN, Rosenbloom DIS, Lewis MG, Hattersley J, Li B, Hesselgesser J, Geleziunas R, Robb ML, Kim JH, Michael NL, Barouch DH. Rapid seeding of the viral reservoir prior to SIV viraemia in rhesus monkeys. Nature. 2014;512:74-7.

23. Ananworanich J, Schuetz A, Vandergeeten C, Sereti I, de Souza M, Rerknimitr R, Dewar R, Marovich M, van Griensven F, Sekaly R, Pinyakorn S, Phanuphak N, Trichavaroj R, Rutvisuttinunt W, Chomchey N, Paris R, Peel S, Valcour V, Maldarelli F, Chomont N, Michael N, Phanuphak P, Kim JH. RV254/SEARCH 010 Study Group: impact of multi-targeted antiretroviral treatment on gut T cell depletion and HIV reservoir seeding during acute HIV infection. PLoS ONE. 2012;7:e33948.

24. Brenchley JM, Price DA, Douek DC. HIV disease: fallout from a mucosal catastrophe? Nat Immunol. 2006;7:235-9.

25. Costiniuk CT, Angel JB. Human immunodeficiency virus and the gastrointestinal immune system: does highly active antiretroviral therapy restore gut immunity? Mucosal Immunol. 2012;5:596-604.

26. Morlat P. Prise en charge médicale des personnes vivant avec le VIH (rapport 2013): Recommandations du groupe d'experts. La Documentation Française ed. Paris; 2013

27. Schuetz A, Deleage C, Sereti I, Rerknimitr R, Phanuphak N, Phuang-Ngern Y, Estes JD, Sandler NG, Sukhumvittaya S, Marovich M, Jongrakthaitae S, Akapirat S, Fletscher JLK, Kroon E, Dewar R, Trichavaroj R, Chomchey N, Douek DC, O Connell RJ, Ngauy V, Robb ML, Phanuphak P, Michael NL, Excler J-L, Kim JH, de Souza MS, Ananworanich J, RV254/SEARCH 010 and RV304/SEARCH 013 Study Groups. Initiation of ART during early acute HIV infection preserves mucosal Th17 function and reverses HIV-related immune activation. PLoS Pathog. 2014;10:e1004543.

28. Day CL, Kaufmann DE, Kiepiela P, Brown JA, Moodley ES, Reddy S, Mackey EW, Miller JD, Leslie AJ, DePierres C, Mncube Z, Duraiswamy J, Zhu B, Eichbaum Q, Altfeld M, Wherry EJ, Coovadia HM, Goulder PJR, Klenerman P, Ahmed R, Freeman GJ, Walker BD. PD-1 expression on HIV-specific T cells is associated with T-cell exhaustion and disease progression. Nature. 2006:443:350-4

29. Petrovas C, Casazza JP, Brenchley JM, Price DA, Gostick E, Adams WC, Precopio ML, Schacker T, Roederer M, Douek DC, Koup RA. PD-1 is a regulator of virus-specific $C D 8^{+}$T cell survival in HIV infection. J Exp Med. 2006;203:2281-92.

30. Caradonna L, Amati L, Magrone T, Pellegrino NM, Jirillo E, Caccavo D. Enteric bacteria, lipopolysaccharides and related cytokines in inflammatory bowel disease: biological and clinical significance. J Endotoxin Res. 2000;6:205-14.

31. Cooke KR, Olkiewicz K, Erickson N, Ferrara JLM. The role of endotoxin and the innate immune response in the pathophysiology of acute graft versus host disease. J Endotoxin Res. 2002;8:441-8.
32. Chege D, Sheth PM, Kain T, Kim CJ, Kovacs C, Loutfy M, Halpenny R, Kandel G, Chun T-W, Ostrowski M, Kaul R, Toronto Mucosal Immunology Group. Sigmoid Th17 populations, the HIV latent reservoir, and microbial translocation in men on long-term antiretroviral therapy. AIDS Lond Engl. 2011:25:741-9.

33. Macal M, Sankaran S, Chun T-W, Reay E, Flamm J, Prindiville TJ, Dandekar $\mathrm{S}$. Effective $\mathrm{CD}^{+}{ }^{\top}$-cell restoration in gut-associated lymphoid tissue of HIV-infected patients is associated with enhanced Th17 cells and polyfunctional HIV-specific T-cell responses. Mucosal Immunol. 2008;1:475-88

34. Kök A, Hocqueloux L, Hocini H, Carrière M, Lefrou L, Guguin A, Tisserand P, Bonnabau H, Avettand-Fenoel V, Prazuck T, Katsahian S, Gaulard P, Thiébaut R, Lévy Y, Hüe S. Early initiation of combined antiretroviral therapy preserves immune function in the gut of HIV-infected patients. Mucosal Immunol. 2015;8:127-40.

35. Cicala C, Martinelli E, McNally JP, Goode DJ, Gopaul R, Hiatt J, Jelicic K, Kottilil S, Macleod K, O'Shea A, Patel N, Van Ryk D, Wei D, Pascuccio M, Yi L, McKinnon L, Izulla P, Kimani J, Kaul R, Fauci AS, Arthos J. The integrin a4 $\beta 7$ forms a complex with cell-surface CD4 and defines a T-cell subset that is highly susceptible to infection by HIV-1. Proc Natl Acad Sci USA. 2009;106:20877-82.

36. YukI SA, Shergill AK, Girling V, Li Q, Killian M, Epling L, Li P, Kaiser P. Haase A Havlir DV, McQuaid K, Sinclair E, Wong JK. Site-specific differences in T cell frequencies and phenotypes in the blood and gut of HIV-uninfected and ART-treated HIV + adults. PLoS ONE. 2015;10:e0121290.

37. Iwata M, Hirakiyama A, Eshima Y, Kagechika H, Kato C, Song S-Y. Retinoic acid imprints gut-homing specificity on T cells. Immunity. 2004;21:527-38.

38. De Milito A. B lymphocyte dysfunctions in HIV infection. Curr HIV Res. 2004;2:11-21.

39. Mattapallil JJ, Douek DC, Hill B, Nishimura Y, Martin M, Roederer M. Massive infection and loss of memory $\mathrm{CD}^{+} \mathrm{T}$ cells in multiple tissues during acute SIV infection. Nature. 2005:434:1093-7.

40. Ramratnam B, Ribeiro R, He T, Chung C, Simon V, Vanderhoeven J, Hurley A, Zhang L, Perelson AS, Ho DD, Markowitz M. Intensification of antiretroviral therapy accelerates the decay of the HIV-1 latent reservoir and decreases, but does not eliminate, ongoing virus replication. J Acquir Immune Defic Syndr. 1999;2004(35):33-7.

41. Finzi D, Hermankova M, Pierson T, Carruth LM, Buck C, Chaisson RE, Quinn TC, Chadwick K, Margolick J, Brookmeyer R, Gallant J, Markowitz M, Ho DD, Richman DD, Siliciano RF. Identification of a reservoir for HIV-1 in patients on highly active antiretroviral therapy. Science. 1997;278:1295-300

42. Chun T-W, Nickle DC, Justement JS, Meyers JH, Roby G, Hallahan CW, Kottilil S, Moir S, Mican JM, Mullins JI, Ward DJ, Kovacs JA, Mannon PJ, Fauci AS. Persistence of HIV in gut-associated lymphoid tissue despite long-term antiretroviral therapy. J Infect Dis. 2008;197:714-20.

43. Lampinen TM, Critchlow CW, Kuypers JM, Hurt CS, Nelson PJ, Hawes SE, Coombs RW, Holmes KK, Kiviat NB. Association of antiretroviral therapy with detection of HIV-1 RNA and DNA in the anorectal mucosa of homosexual men. AIDS Lond Engl. 2000;14:F69-75.

44. Di Stefano M, Favia A, Monno L, Lopalco P, Caputi O, Scardigno AC, Pastore G, Fiore JR, Angarano G. Intracellular and cell-free (infectious) HIV-1 in rectal mucosa. J Med Virol. 2001;65:637-43.

45. Hey-Cunningham WJ, Murray JM, Natarajan V, Amin J, Moore CL, Emery S, Cooper DA, Zaunders J, Kelleher AD, Koelsch KK. PINT study team: early antiretroviral therapy with raltegravir generates sustained reductions in HIV reservoirs but not lower T-cell activation levels. AIDS Lond Engl. 2015;29:911-9.

46. Hunt PW, Brenchley J, Sinclair E, McCune JM, Roland M, Page-Shafer K, Hsue P, Emu B, Krone M, Lampiris H, Douek D, Martin JN, Deeks SG. Relationship between $\mathrm{T}$ cell activation and $\mathrm{CD}^{+}{ }^{+} \mathrm{T}$ cell count in HIVseropositive individuals with undetectable plasma HIV RNA levels in the absence of therapy. J Infect Dis. 2008;197:126-33.

47. Sarmati L, D’Ettorre G, Parisi SG, Andreoni M. HIV replication at low copy number and its correlation with the HIV reservoir: a clinical perspective. Curr HIV Res. 2015;13(3):250-7.

48. Saison J, Demaret J, Venet F, Chidiac C, Malcus C, Poitevin-Later F, Tardy $\mathrm{J}$-C, Ferry T, Monneret G. $\mathrm{CD}^{+} \mathrm{CD}^{2} 5^{+} \mathrm{CD} 127^{-}$assessment as a surrogate phenotype for FOXP3 ${ }^{+}$regulatory $\mathrm{T}$ cells in $\mathrm{HIV}-1$ infected viremic and aviremic subjects. Cytom B Clin Cytom. 2013;84:50-4. 
49. Arroyo-Villa I, Bautista-Caro M-B, Balsa A, Aguado-Acín P, Nuño L, Bonilla-Hernán M-G, Puig-Kröger A, Martín-Mola E, Miranda-Carús M-E. Frequency of Th17 CD4 ${ }^{+} \mathrm{T}$ cells in early rheumatoid arthritis: a marker of anti-CCP seropositivity. PLoS ONE. 2012;7:e42189.

50. Annunziato F, Cosmi L, Santarlasci V, Maggi L, Liotta F, Mazzinghi B, Parente E, Fili L, Ferri S, Frosali F, Giudici F, Romagnani P, Parronchi P, Tonelli F, Maggi E, Romagnani S. Phenotypic and functional features of human Th17 cells. J Exp Med. 2007:204:1849-61.

51. Gosselin A, Monteiro P, Chomont N, Diaz-Griffero F, Said EA, Fonseca S, Wacleche V, El-Far M, Boulassel M-R, Routy J-P, Sekaly R-P, Ancuta P. Peripheral blood CCR4 ${ }^{+} \mathrm{CCR}^{+}$and $\mathrm{CXCR}_{3}{ }^{+} \mathrm{CCR}^{+}{ }^{+} \mathrm{CD}_{4}^{+} \mathrm{T}$ cells are highly permissive to HIV-1 infection. J Immunol. 1950;2010(184):1604-16.

52. O'Connor AM, Crawley AM, Angel JB. Interleukin-7 enhances memory CD8(+) T-cell recall responses in health but its activity is impaired in human immunodeficiency virus infection. Immunology. 2010;131:525-36.

53. Ladell K, Hellerstein MK, Cesar D, Busch R, Boban D, McCune JM. Central memory $C D 8^{+} T$ cells appear to have a shorter lifespan and reduced abundance as a function of HIV disease progression. J Immunol. 1950;2008(180):7907-18.
54. Hunt PW, Sinclair E, Rodriguez B, Shive C, Clagett B, Funderburg N, Robinson J, Huang Y, Epling L, Martin JN, Deeks SG, Meinert CL, Van Natta M, Jabs DA, Lederman MM: Gut epithelial barrier dysfunction and innate immune activation predict mortality in treated HIV infection. J Infect Dis. 2014.

55. Zhou J, Cheung AK, Liu H, Tan Z, Tang X, Kang Y, Du Y, Wang H, Liu L, Chen Z. Potentiating functional antigen-specific $\mathrm{CD} 8^{+} \mathrm{T}$ cell immunity by a novel PD1 isoform-based fusion DNA vaccine. Mol Ther. 2013;21:1445-55.

56. Anolik JH, Looney RJ, Lund FE, Randall TD, Sanz I. Insights into the heterogeneity of human B cells: diverse functions, roles in autoimmunity, and use as therapeutic targets. Immunol Res. 2009;45:144-58.

57. Bohnhorst JØ, Bjørgan MB, Thoen JE, Natvig JB, Thompson KM. Bm1-Bm5 classification of peripheral blood $B$ cells reveals circulating germinal center founder cells in healthy individuals and disturbance in the B cell subpopulations in patients with primary Sjögren's syndrome. J Immunol. 1950;2001(167):3610-8.

\section{Submit your next manuscript to BioMed Central and we will help you at every step:}

- We accept pre-submission inquiries

- Our selector tool helps you to find the most relevant journal

- We provide round the clock customer support

- Convenient online submission

- Thorough peer review

- Inclusion in PubMed and all major indexing services

- Maximum visibility for your research

Submit your manuscript at www.biomedcentral.com/submit 